\title{
On the money
}

\author{
Increases in governmental funding for research are outmatched by the swelling ranks of scientists \\ competing for grants. Physicists are starting to look for creative alternatives to complement \\ theirfunding.
}

The next time you pen a grant proposal, consider throwing in a pledge to name your discovery after the offspring of the funding body's CEO. That's reportedly how Galileo Galilei did it - naming the satellites of Jupiter for the daughters of a prospective patron, Cosimo II de' Medici.

The history of patronage has pages in many corners of the world, but it's arguably most frequently associated with Florence, perhaps due to the strife that Galileo found himself in when his views conflicted with those of his patrons. Patronage was a way of life in Florence - an avenue for bright young things who were socio-economically disadvantaged to seize enough financial autonomy to develop their craft.

The institutionalization of science beginning in the 1660s with the founding of the Royal Society of London and the Académie des sciences in Paris - set the wheels in motion for the end of academic patronage. It was, by many accounts, a welcome change. The credibility of scientific research slowly came to rely on benchmarks such as experimental success, instead of simply reflecting the reputation of its patron.

Favourable though it may have been, the movement has ultimately led to a system that may be compromised in the modern age by insufficient funding. As the website for a new fundraising platform (www.experiment.com) points out, "Since $2010,80 \%$ of principal investigators spend more time writing grant proposals and $67 \%$ are struggling with less funding. 'Big science' has become synonymous with 'budget cuts." Might there be scope within our current funding environment for patronage to make a comeback?

In a Commentary published in this issue (page 700), Ioannis Pavlidis and colleagues examine the merit structures in place to award tenure and funding to researchers, and note that they have failed to evolve with the modern scientific method, which thrives on collaboration. Indeed, it seems that scientists are now looking beyond the university structure to maintain adequate funding for their research.

One example is the recent acquisition of the personnel from the lab of John Martinis at the University of California, Santa Barbara by Google's Quantum Artificial Intelligence Lab. Announced in a blog post last month ${ }^{1}$, the new venture is a bold move for both parties. The plan is for Martinis to work from Google's Santa Barbara office with UCSB graduate students while continuing to use the university's fabrication and measurement facilities.

One might argue that Google's interests are motivated by the mounting dissent within the quantum-computing community as to the viability of technology the company acquired from D-Wave Systems in 2009. In this respect, it's clear that Martinis offers intellectual credibility to their mission.

\section{It seems that scientists are now looking beyond the university structure to maintain adequate funding for their research.}

But Martinis himself is candid about what he and his team are getting out of the move. Quite apart from the novelty of being the brains behind the 'next big thing' to come out of this corporate giant, his appointment represents an exciting opportunity to - well, to retire from the business of raising funds.

Perhaps more importantly, as Martinis pointed out in a recent interview ${ }^{2}$, the move to Google means that he'll be able to hire staff on a more permanent basis. "With people moving through all the time it's hard to have the continuity to keep going," he said. "We're at the point where things are complicated and we need the permanent staff. Now they will be able to focus on this and commit for a long term to bring this technology to the next level."

High-profile acquisitions may sit on one end of the career spectrum, but the other end is experiencing change of its own. As funding rates decline and the number of scientists applying for a dwindling pool of grants balloons, researchers on the lower rungs of the career ladder are beginning to take matters into their own hands.
Tapping into the inherent appeal of well-communicated science, researchers have been looking to crowd-funding platforms as a means of raising the funds required to complete their projects. The trend has even motivated the launch of new platforms tailored specifically to promote scientific research. The benefits are twofold. By engaging the community in an effort to raise money, scientists are simultaneously generating publicity for their work, and creating an incentive for turnaround times that might otherwise be considered impossible.

Science-specific crowd-funding platforms like Experiment and Thinkable (www.thinkable.org) are pitch perfect in this sense. They not only provide the necessary security for financial transfers, but also create a forum for potential donors to follow scientific progress in real time. Researchers are encouraged to provide regular updates on their projects and post videos showcasing highlights of their work.

And there is little room for doubt in terms of their legitimacy. To join the Thinkable platform, scientists require an affiliation with a university or research institution and must put forward two referees in support of their work. Projects currently raising money through Experiment include a bid to build the world's smallest solar cell and a method for targeted drug delivery using magnetic nanoparticles.

To the upper echelons of 17 th century Florentine society, this would likely all seem self-evident. Although it was true that the reputation of the patron influenced that of the client, it was undoubtedly a two-way street: patronage was the key to social status in Florence. It has even been said that patronage was voluntary "only in the sense that by not engaging in it one would commit social suicide."3 Although the push for state-funded research remains essential, perhaps there is room for alternative models to become comparable social imperatives.

\footnotetext{
References

1. http://go.nature.com $/ \mathrm{c} 6 \mathrm{NqB}$ )

2. Finley, K. Wired (5 September 2014); http://www.wired. com/2014/09/martinis

. Biagioli, M. History of Science 28, 1-62 (1990).
} 